\title{
Soil and entomopathogenic fungi with potential for biodegradation of insecticides: degradation of flubendiamide in vivo by fungi and in vitro by laccase
}

\author{
George M. Yada Jr ${ }^{1}$ (D) - Igor S. Shiraishi ${ }^{1}$ (D) Robert F. H. Dekker $^{1}$ (D) Jéseka G. Schirmann ${ }^{2}$ (D) \\ Aneli M. Barbosa-Dekker ${ }^{2}$ (I) - Isabela C. de Araujo ${ }^{1}$ (D) $\cdot$ Lucas M. Abreu $^{3}$ (D) - Juliana F. S. Daniel ${ }^{1}$ (D)
}

Received: 27 June 2019 / Accepted: 11 November 2019/Published online: 25 November 2019

(C) The Author(s) 2019

\begin{abstract}
Purpose Flubendiamide is a highly toxic and persistent insecticide that causes loss of insect muscle functions leading to paralysis and death. The objective was to screen for filamentous fungi in soils where insecticides had been applied, to isolate entomopathogenic fungi from insect larva (Anticarsia gemmatalis) that infest soybean crops, and to use these in biodegradation of insecticides.

Method Filamentous fungi were isolated from soils, and growth inhibition was evaluated on solid medium containing commercial insecticides, Belt ${ }^{\circ}$ (flubendiamide) and Actara ${ }^{\circledR}$ (thiamethoxam). A total of 133 fungi were isolated from soil and 80 entomopathogenic fungi from insect larva. Based on growth inhibition tests, ten soil fungi, 2 entomopathogenic fungi, and Botryosphaeria rhodina MAMB-05 (reference standard) were selected for growth on commercial insecticides in solid media. Fungi were grown in submerged fermentation on media containing commercial insecticides and assayed for laccase activity. Result Isolates JUSOLCL039 (soil), JUANT070 (insect), and MAMB-05 performed best, and were respectively inhibited by $48.41 \%, 75.97 \%$, and $79.23 \%$ when cultivated on $35 \mathrm{~g} / \mathrm{L} \mathrm{Actara}{ }^{\circledR}$, and $0.0,5.42 \%$, and $43.39 \%$ on $39.04 \mathrm{~g} / \mathrm{L}$ Belt $\circledast$. JUSOLCL039 and JUANT070 were molecularly identified as Trichoderma koningiopsis and Neurospora sp., respectively. The three fungal isolates produced laccase constitutively, albeit at low activities. Fungal growth on pure flubendiamide and thiamethoxam resulted in only thiamethoxam inducing high laccase titers $(10.16 \mathrm{U} / \mathrm{mL})$ by JUANT070. Neurospora $\mathrm{sp}$. and B. rhodina degraded flubendiamide by $27.4 \%$ and $9.5 \%$ in vivo, while a crude laccase from B. rhodina degraded flubendiamide by $20.2 \%$ in vitro.

Conclusion This is the first report of fungi capable of degrading flubendiamide, which have applications in bioremediation.
\end{abstract}

Keywords Anticarsia gemmatalis (larval) endophytic fungi · Botryosphaeria rhodina MAMB-05 · Neurospora sp. JUANT070 · Trichoderma koningiopsis JUSOLCL039 · Commercial insecticides Belt $®$ and Actara ${ }^{\circledR}$ · Thiamethoxam

Electronic supplementary material The online version of this article (https://doi.org/10.1007/s13213-019-01536-w) contains supplementary material, which is available to authorized users.

Juliana F. S. Daniel

julianasouza@utfpr.edu.br

1 Programa de Pós-Graduação em Engenharia Ambiental, Universidade Tecnológica Federal do Paraná, Câmpus Londrina, Londrina, PR CEP: 86036-370, Brazil

2 Departamento de Química-CCE, Universidade Estadual de Londrina, Londrina, PR CEP: 86057-970, Brazil

3 Departamento de Fitopatologia, Universidade Federal de Viçosa, Viçosa, MG CEP: 36570-900, Brazil

\section{Introduction}

Brazil is the world's largest consumer of pesticides with over 1500 commercial products registered by the Brazilian Minister of Agriculture (Caldas et al. 2018). About one-third of its annual pesticide consumption ( billion liters) is applied to soybean crops, Brazil's main cash crop. The high consumption of pesticides in Brazil is therefore a public safety concern for their disposal, contamination, and accumulation in the environment.

Among the insecticides commonly applied to agricultural crops in Brazil are flubendiamide and thiamethoxam. Flubendiamide (marketed by Bayer as Belt $\AA$ ) has in its chemical structure an iodine substituent (Fig. 1a), an unusual 
Fig. 1 Chemical structures of the insecticides flubendiamide (a) and thiamethoxam (b)

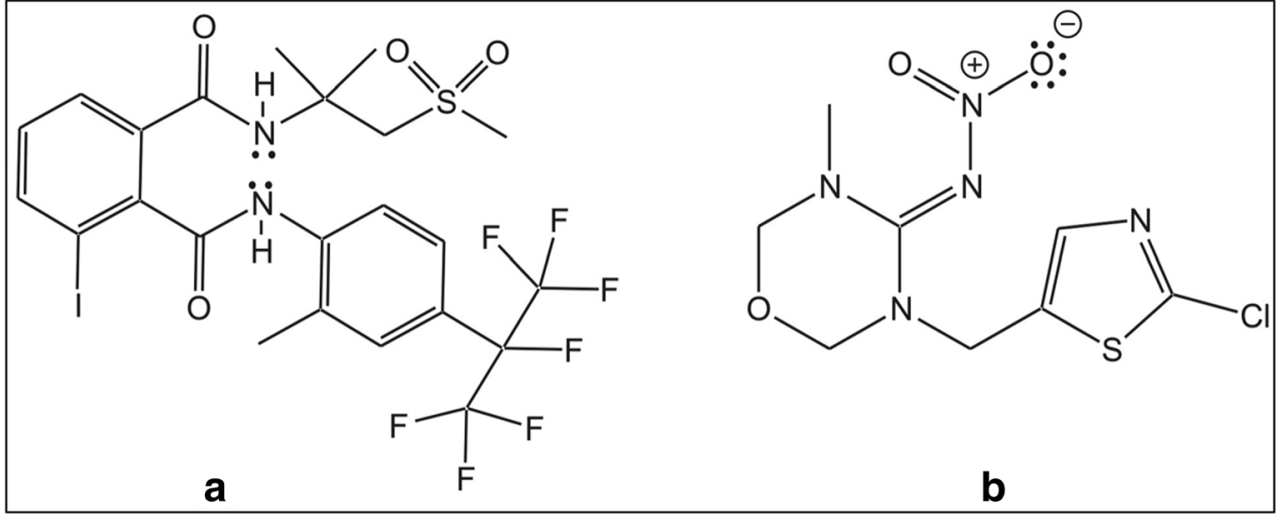

structural feature for a crop protectant. Flubendiamide belongs to the ryanoid class of insecticides containing a diamide group of phthalates, and is widely used to control lepidopteran pests in a variety of annual and perennial crops including soybeans. Flubendiamide causes loss of insect muscle function leading to paralysis and death (Masaki et al. 2006). Flubendiamide is highly persistent in the environment (a toxicity-class III, Group 28 crop-insecticide) and highly toxic to marine organisms important to the aquatic food chain (USA, EPA 2008).

Actara ${ }^{\circledR}$ (marketed by Syngenta), whose active ingredient is thiamethoxam (Fig. 1b), is a broad-spectrum, systemic insecticide, a second-generation neonicotinoid, that combats sucking and chewing insect pests, and is applied to the leaves of several plants of agricultural importance.

The indiscriminate use of a variety of pesticides has led to public concern about the adverse effects on the environment and public health, resulting from the production, application, and disposal of pesticides. Faced with this problem, we were interested to study the fate of flubendiamide by soilremediating fungi and its transformation products. Studies on flubendiamide and thiamethoxam insecticides in Brazil are scarce, and to evaluate their bioremediation, we preferably screened soil filamentous fungi, which are known to possess high degradative capacity and resistance to adverse environmental conditions. The main route to the degradation of flubendiamide in field-soil appears to be through direct photolysis to produce the metabolite, deiodo-flubendiamide (Das et al. 2017), but the soil types and soil microbiome also influences its degradation (Das and Mukherjee 2012). Microbial degradation studies of pesticides in soils with different physicochemical properties are essential to evaluate the persistence of pesticides. The importance and influence of the use of select fungi can help in the biodegradation of more toxic insecticides, reducing their half-life (Ruegger and Tauk-Tornisielo 2004).

In studies involving the biodegradation of insecticides, fungi are an interesting biological tool to employ because of their metabolic machinery. They grow rapidly on defined culture media. Knowledge of the microbial degradation of flubendiamide contributes to the correct application of the pesticide to agricultural crops and in environmental safety. The metabolism of pesticides by microorganisms is influenced by their enzyme systems, and the chemical structure of the pesticides themselves. Detection and quantification of flubendiamide and its metabolite, deiodo-flubendiamide, have been reported through chromatographic techniques (Das and Mukherjee 2012).

The objectives of the work reported herein was to screen and select fungi isolated from soil from farm fields in the Londrina region where soybean crops were grown, and where insecticides had been applied over several years, and to use these fungi to study growth inhibition of the insecticides: Belt $\AA$ (Bayer) and Actara ${ }^{\circledR}$ (Syngenta), and to evaluate if these insecticides can induce fungal laccases. We were also interested to analyze the biodegradation of pure flubendiamide in vivo by a entomopathogenic fungus (JUANT0-70) isolated from the tropical insect, Anticarsia gemmatalis (larval form) that infests soybean crops in Brazil, along with Botryosphaeria rhodina MAMB-05, a ligninolytic ascomycete (Dekker et al. 2002). In addition, we assessed the degradation of flubendiamide in vitro using a laccase preparation from B. rhodina MAMB- 05 .

\section{Methods}

\section{Insecticides}

The insecticides used in this study, flubendiamide (98.5\% analytical standard) and its commercial formulation Belt ${ }^{\circledR}$ containing $48 \%$ flubendiamide, were provided by Bayer S.A., Brazil. A flubendiamide analytical standard (Pestanal®, 98.6\%) was purchased from Fluka Analytica (SigmaAldrich, Sao Paulo, Brazil). The insecticide, thiamethoxam (99\%, analytical standard; Sigma-Aldrich, Brazil), and its corresponding commercial product Actara ${ }^{\circledR}$ containing $25 \%$ thiamethoxam, was obtained from Syngenta, Brazil. 


\section{Soil collection and isolation of filamentous fungi}

Fungi were isolated from soils classified as distroferric red latosol due to its high clay content that is typical in the region of Londrina, Brazil (Lemos and Santos 1984). Soil was collected from an agricultural farm (Fazenda São Manoel) located nearby the campus of Universidade Tecnológica Federal do Paraná, that had previously cultivated soybeans and had applied 2 commercial insecticides (PlatinumNeo ${ }^{\circledR}$ and Prêmioß). The farm was divided into three distinct sectors to compare soils where the different commercial insecticides were applied: (i) PlatinumNeo®—-thiamethoxam as active principle); (ii) Prêmio ${ }^{\circledR}$ — chlorantraniliprole as active principle); and (iii) an area where no insecticides had been applied. Soil samplings were performed once weekly in the mornings from March to May 2014. In each sector of the agricultural areas sampled, 10 soil samples ( 100 g per week) were collected at random at a depth of $0-15 \mathrm{~cm}$. The physical and chemical characteristics of the soils were analyzed at the Instituto Agronômico do Paraná (IAPAR, Londrina-PR, Brazil) and included the following: soil texture, $\mathrm{pH}$, and analysis for content of carbon, aluminum, phosphorus, potassium, and magnesium.

\section{Isolation of fungi}

Fungi were isolated from soils collected in the three sectors on the farm as described above by employing the serial dilution method (Colla et al. 2008). Ten grams of soil taken from each sector were transferred into 500-mL Erlenmeyer flasks containing $90 \mathrm{~mL}$ of sterile distilled water and stirred at $150 \mathrm{rpm}$ for $15 \mathrm{~min}$. Samples of $1 \mathrm{~mL}$ were removed and diluted 10fold with sterile water. From this, 1-mL aliquots were withdrawn and serially diluted 100-, 1000-, and 10,000-fold with sterile water. Aliquots of $0.1 \mathrm{~mL}$ taken from each of these dilutions were spread onto agar media (PDA, potato-dextrose-agar, Acumedia, Jundiaí-São Paulo, Brazil) supplemented with the antibiotic neomycin $(16 \mu \mathrm{g} / \mathrm{mL})$ in Petri dishes, and left for 7 days at $25^{\circ} \mathrm{C}$ in an incubator. Growing fungal colonies were successively isolated using sterilized wooden toothpicks and replated on PDA plates until a pure colony was obtained. The axenic fungi isolated were subcultured on PDA and maintained at $4{ }^{\circ} \mathrm{C}$, and were preserved by the Castellani method (Rodrigues et al. 1992). One hundred and thirty-three fungi were isolated from the soil samples collected.

Fungi were also isolated from the tropical insect, Anticarsia gemmatalis (larval form) that infests soybean crops in Brazil. Caterpillars (larvae) were collected from a soybean crop on Fazenda São Manoel in 2014, and were separately left in plastic containers until they died. The larvae were then surface sterilized by the following sequential procedure: immersion in $70 \%$ ethanol ( $3 \mathrm{~s})$, sodium hypochlorite $(10 \mathrm{~s})$ and sterile water ( $3 \mathrm{~s})$. The sterilized larvae were next transferred aseptically to Petri dishes containing a cotton-wool ball soaked in sterile water to create moist conditions and left in the incubator at $28{ }^{\circ} \mathrm{C}$ to allow growth of endophytic fungi inside the insects (Alves 1998). After 7 days, the caterpillars were cut with a scalpel and placed inverted on agar (PDA medium) inside Petri dishes, and incubated for a further 7 days. Fungal colonies (endophytes) growing out of the larvae on the PDA plates augmented with neomycin were isolated and purified. Eighty-one fungi were isolated from 80 larvae collected, and were designated using the JUANT coding prefix.

\section{DNA sequencing and phylogenetic analyses}

Fungal isolates JUANT070 (insect larva) and JUSOLCL039 (soil) were cultivated on $2 \%(\mathrm{w} / \mathrm{v})$ malt extract-agar (MEA; HiMedia Laboratories, USA) for five days at $24{ }^{\circ} \mathrm{C}$. Preliminary morphological evaluation of colony aspects and microscopic characteristics of conidiophores and conidia suggested that the isolates belonged to the genus Neurospora and Trichoderma, respectively (Domsch et al. 2007).

Mycelium was scrapped from 5-day-old cultures on MEA, macerated under liquid nitrogen, and subjected to genomic DNA extraction using the Wizard ${ }^{\circledR}$ Genomic DNA Purification Kit (Promega, Madison, USA). A fragment of the second largest subunit of the ribonucleic acid (RNA) polymerase gene (RPB2) was amplified from the extracted DNA using the primers 5F (fRPB2-5FGAYGAYMGWGATCAYTTYGG) and 7cR (fRPB2-7cRCCCATRGCTTGYTTRCCCAT), and the polymerase chain reaction (PCR) conditions described by Liu et al. (1999). The purified PCR products were sent to a commercial company for DNA sequencing.

Consensus sequences were assembled using SeqAssem ver. 07/2008 (SequentiX-Digital DNA Processing, Germany). Blast searches against the GenBank database confirmed that the isolates belonged to the genera Neurospora and Trichoderma. Partial RPB2 DNA sequences from reference strains of Neurospora species from the Fungal Genetics Stock Center and other collections were retrieved from GenBank, or through blast searches against the genome sequences available at the Mycocosm portal of the Joint Genome Institute (Grigoriev et al. 2014). Sequences of RPB2 from reference strains of Trichoderma from the published works of Chaverri et al. (2015) and Montoya et al. (2016) were retrieved from GenBank. Multiple sequence alignments were composed for each genus using the Multiple Sequence Comparison by Log-Expectation (MUSCLE) tool, as implemented by MEGA 7 software. Maximum Parsimony (MP) phylogenetic analyses were conducted in MEGA 7 using the following parameters: 10 initial trees generated by random sequence additions; MP tree search by Tree Bisection-Regrafting (TBR) algorithm, level 1; 1000 
bootstrap pseudo-replicates for node support estimation. The out-group used for the Neurospora phylogenetic tree was Sordaria fimicola CBS 723.96, while Trichoderma eucorticioides GJS 99-61 was used for the Trichoderma tree.

\section{Fungal growth inhibition tests}

One hundred and thirty-three fungi isolated from soil taken from a farm where commercial insecticides had been applied to crops were cultivated on solid media (PDA). Among these, 10 fungi grew rapidly and had the largest colony diameters, and were selected for further studies on growth inhibition using the commercial insecticides: Belt ${ }^{\circledR}$ and Actara ${ }^{\circledR}$ at various concentrations. Growth inhibition assays were carried out to determine and select fungi capable of growing on the insecticides, and were used in experiments on the biodegradation of flubendiamide.

To choose the range of commercial insecticide concentrations, Botryosphaeria rhodina MAMB-05 was selected as a reference fungus, as this ascomyceteous fungus was previously reported to grow on the herbicide, Scepter® (Rezende et al. 2005).

Actara ${ }^{\circledR}$ and Belt ${ }^{\circledR}$ that had separately been added to PDA media were gently heated before use to melt the agar, which was then dispensed into Petri dishes $(20 \mathrm{~mL})$ and allowed to solidify. The plates were inoculated with an agar plug (diam. $1 \mathrm{~cm}$ ) taken from an agar plate (PDA, no insecticides) freshly colonized with mycelium of the fungal isolates, and incubated for 7 days at $28^{\circ} \mathrm{C}$. The range of the insecticide concentrations selected for testing represent low, intermediate, and high concentrations of the insecticides, and were incorporated into PDA; Actara ${ }^{\circledR}(0-30 \mathrm{~g} / \mathrm{L})$, and Belt ${ }^{\circledR}(0-80 \mathrm{~g} / \mathrm{L})$, and the plates inoculated with $B$. rhodina MAMB- 05 , and left to grow for 7 days at $28{ }^{\circ} \mathrm{C}$. Under these conditions, the growth at which $50 \%$ inhibition $\left(\mathrm{IC}_{50}\right)$ occurred was $12.6 \mathrm{~g} / \mathrm{L}$ for Actara ${ }^{\circledR}$ and $31.42 \mathrm{~g} / \mathrm{L}$ for Belt ${ }^{\circledR}$. Plots of percentile growth versus commercial insecticide concentration $(\mathrm{g} / \mathrm{L})$ resulted in linearity over the ranges examined (Actara $(\mathbb{2}: y=2.515 x+$ 18.294; $\left.r^{2}=0.9820\right)$, and Belt@: $y=0.630 x+30.205 ; r^{2}=$ 0.9866), and are shown in Supplementary Materials, Figures 1 and 2). Four concentrations of each commercial insecticide were chosen based upon the results obtained with B. rhodina MAMB-05; Actara ${ }^{\circledR}(3,7,21$, and $35 \mathrm{~g} / \mathrm{L})$, and Belt $(1.22,4.88,19.52$, and $39.04 \mathrm{~g} / \mathrm{L})$, and were used to evaluate fungal growth inhibition.

In the growth inhibition experiments, ten of the most promising fungal isolates collected from the soil samples, as well as two insect larval fungi (JUANT001 and JUANT070), together with $B$. rhodina MAMB-05, were cultivated over 7 days in Petri dishes on PDA media containing increasing concentrations of each of the commercial insecticides, Belt ${ }^{\circledR}$ and Actara ${ }^{\circledR}$, as described above. Cultivations were carried out in replicates of three for each concentration of the insecticides evaluated.

Growth inhibition was estimated from Eq. 1 by measuring the four equidistant diameters $(\mathrm{cm})$ of the growing fungal colonies on the agar plates compared with control cultures containing no insecticides (Birolli et al. 2015).

$I=\frac{A-B}{A} \times 100 \%$

where $I$ is the growth inhibition (\%); A, average growth diameter in medium containing no insecticide (control); and B, mean growth diameter in medium with insecticide.

\section{Statistical analysis}

The experimental design of the growth inhibition assays in solid medium was completely randomized in a $13 \times 4$ factorial design (13 fungal isolates $\times 4$ insecticide concentrations) with three replications. The results were evaluated by analysis of variance (ANOVA), and the means were compared by the Scott-Knott test at $5 \%$ probability. The data were analyzed by R software Core Team 2013 (version 3.2.0).

\section{Production of laccase by Botryosphaeria rhodina MAMB-05}

B. rhodina isolate MAMB-05 (Barbosa et al. 1996) was grown on basal medium $(10 \mathrm{~g} / \mathrm{L}$ glucose and Vogel minimum salts medium (Vogel 1956), $\mathrm{pH}$ 5.8; to which the laccase inducer, veratryl alcohol $(30.4 \mathrm{mM})$, had been added at timepoint zero, and the cultures grown in liquid submerged fermentation at $28{ }^{\circ} \mathrm{C}(200 \mathrm{rpm})$ for $72 \mathrm{~h}$ under conditions described for the optimization of laccase production by Vasconcelos et al. (2000) for this fungus. Thereafter, the cultures were harvested by centrifugation $(1200 \times \mathrm{g} / 30 \mathrm{~min})$, and the supernatant recovered and used as the source of laccase in this study. The supernatant was dialyzed exhaustively against distilled water at $4{ }^{\circ} \mathrm{C}$ with frequent changes of water over a 48 -h period. The dialyzate was then freeze-dried, and the powdered preparation stored at $-20{ }^{\circ} \mathrm{C}$ until required.

Laccase activity was assayed against the putative substrate ABTS $\left(0.05 \mathrm{M} ; 2,2^{\prime}\right.$-azino-bis (3ethylbenzthiazoline-6-sulfonic acid; Sigma-Aldrich, St. Louis, MO, USA), in $0.25 \mathrm{M}$ citrate-phosphate buffer solution $\left(\mathrm{pH} \mathrm{3.0)}\right.$ at $50{ }^{\circ} \mathrm{C}$ for $5 \mathrm{~min}$, and the absorbance measured spectrophotometrically at $420 \mathrm{~nm}$ (molar extinction coefficient $(\varepsilon)$ of ABTS is $36,000 \mathrm{~mol}^{-1} \mathrm{~cm}^{-1}$ ) (Dekker and Barbosa 2001). The unit of laccase activity is defined as the number of $\mu$ moles of ABTS oxidized per min under the assay conditions. 


\section{Assessment of laccase production by isolates JUANT070, JUSOLCL39, and Botryosphaeria rhodina MAMB-05 cultivated on liquid medium in the presence of insecticides: Actara ${ }^{\circledR}$, Belt ${ }^{\circledast}$, flubendiamide, and thiamethoxam}

Isolates JUANT070, JUSOLCL39, and B. rhodina MAMB05 were chosen on the basis of having the lowest degree of growth inhibition on the two commercial insecticides evaluated, and were assessed for their ability to induce laccase when cultivated on each of the two commercial formulated insecticides (Belt $\AA$ and Actara $\AA$ ), as well as on pure samples of flubendiamide and thiamethoxam.

Pre-inoculum was produced by cultivating isolates JUANT070 and MAMB-05 on agar plates (PDA, no insecticide) for 7 days at $28{ }^{\circ} \mathrm{C}$. Six 1 -cm diam. agar plugs taken from the mycelial-colonized agar plates were transferred to $125-\mathrm{mL}$ Erlenmeyer flasks containing basal medium $(50 \mathrm{~mL})$. For the sporulating fungus JUSOLCL39, inoculation was carried out using a spore suspension $\left(4 \times 10^{4}\right)$ contained in an aqueous solution of Tween $80(0.1 \%, \mathrm{v} / \mathrm{v})$.

In experiments with the 2 commercial insecticides, the nutrient medium contained $1.22 \mathrm{~g} / \mathrm{L}$ of Belt巴 ${ }^{\circledR}$ and $3.0 \mathrm{~g} / \mathrm{L}$ of Actara ${ }^{\circledR}$, and were inoculated with the aforementioned three fungal isolates, and left under shaking conditions (180 rpm) at $28^{\circ} \mathrm{C}$ for 5,10 , and 20 days. In another experiment following inoculation, the 3 fungal cultures were left to grow under shaking conditions $(180 \mathrm{rpm})$ for $48 \mathrm{~h}$ at $28{ }^{\circ} \mathrm{C}$. At this timepoint, $1 \mathrm{~mL}$ of flubendiamide solution containing $5 \mathrm{mg}$ (analytical standard-Sigma-Aldrich, USA) dissolved in $1 \mathrm{~mL}$ dimethylforamide), and in a separate experiment, $1 \mathrm{~mL}$ of thiamethoxam solution (analytical standardSigma-Aldrich, USA) containing $5 \mathrm{mg}$ dissolved in $1 \mathrm{~mL}$ $10 \%(\mathrm{v} / \mathrm{v}) \mathrm{DMSO})$, were transferred in toto to flasks containing the growing fungi, and shaking continued at $28{ }^{\circ} \mathrm{C}$ for 10 days. The final concentration of both insecticides was $0.1 \mathrm{mg} / \mathrm{mL}$. After cultivation, the fungal cultures were harvested (filtration) and the mycelia and cell-free filtrates recovered. The latter in turn, were assayed for laccase activity against ABTS as substrate. Controls were prepared containing all of the components except the fungal mycelia/spores in order to monitor insecticide losses during the extent of the experiment. All experiments were carried out in triplicate.

\section{Biodegradation of flubendiamide: extraction and analysis}

In the experiment from the previous section, the fungal mycelia recovered and the cell-free filtrates collected from isolates JUANT070 and MAMB-05 grown on pure flubendiamide were examined for the biodegradation of this insecticide. The mycelium was macerated and then extracted with solvent as indicated below to ensure that removal of flubendiamide from the cell-free fermentation broth was not attributable to the insecticide adsorbing onto the mycelium. Both the mycelium and the cell-free fermentation broth were separately extracted three times with ethyl acetate (ratio 1:1), the ethyl acetate phases were collected and pooled, and then the extracts from both samples were combined. Water in the ethyl acetate extracts was removed by addition of solid anhydrous sodium sulfate, and the solvent removed by rotary evaporation (Rotary Evaporator, Fisatom 801, São Paulo-SP, Brazil) under vacuum. The steps involved in the extractions are outlined in the flowsheet in Supplementary Material, Figure 3).

\section{Enzymatic treatment of flubendiamide with a crude laccase preparation from Botryosphaeria rhodina MAMB-05}

A solution of the crude laccase preparation from $B$. rhodina $(0.2 \mathrm{~mL}$ of a $1 \%(\mathrm{w} / \mathrm{v})$ solution) was added to $25-\mathrm{mL}$ Erlenmeyer flasks containing $2.0 \mathrm{~mL}$ of $0.25 \mathrm{M}$ citratephosphate buffer solutions $(\mathrm{pH} 3.0$ and 6.5 were tested to determine the best condition), $1.0 \mathrm{~mL}$ flubendiamide solution in aqueous $70 \% \mathrm{DMF}$, and water to a final volume of $10 \mathrm{~mL}$, and stirred $(30 \mathrm{rpm})$ for $24 \mathrm{~h}$ at $28^{\circ} \mathrm{C}$. The final concentration of flubendiamide was $0.1 \mathrm{mg} / \mathrm{mL}$. The reaction was performed in triplicate. This was followed by extracting the reaction mixture three times with ethyl acetate (1:1) under conditions as described above, and the ethyl acetate phases collected and pooled. Controls contained all of the components in the reaction mixture with the exception of laccase, and were treated under the same conditions including the ethyl acetate extraction steps.

\section{High-performance liquid chromatography analysis of flubendiamide}

The ethyl acetate extracts obtained from the 20-day cell-free fermentation broths of fungal isolates JUANT070 and $B$. rhodina MAMB-05, as well as the laccase-catalyzed reaction mixture ( $24 \mathrm{~h}$ at $\mathrm{pH} 6.5$ ), were analyzed by HPLC on a Shimadzu Chromatograph equipped with a UV detector and coupled to a HPLC reverse-phase column (Phenomenex®, Luna ${ }^{\circ}$, C-18(2), USA). The oven temperature was set at $25{ }^{\circ} \mathrm{C}$ (Battu et al. 2008), and the column was eluted isocratically with acetonitrile:Milli-Q water (ratio 60:40) as mobile phase at a flow rate of $1 \mathrm{~mL} / \mathrm{min}$. The run time for the analysis of each extract was $35 \mathrm{~min}$. The concentration of flubendiamide was determined at $210 \mathrm{~nm}$. The sample injection volume was $20 \mu \mathrm{L}$, and three replicates of all samples were analyzed.

The calibration curves for the flubendiamide standard were linear within the range of 0.1 to $1.0 \mathrm{mg} / \mathrm{mL}$ when added to the culture medium and extracted with ethyl acetate. The 
correlation coefficient $\left(\mathrm{r}^{2}\right)$ was 0.9898 . All samples were dissolved in $2 \mathrm{~mL}$ of acetonitrile (HPLC grade) with the aid of ultrasonication in a ultrasonic bath (TECNAL $\AA$, Brazil), and then filtered through CHROMAFIL $\AA$ syringe filters (Millipore Brazil; porosity $0.20 \mu \mathrm{m}$ ), and the filtrates stored in $2 \mathrm{~mL}$ vials for injection into the chromatograph.

\section{Results and discussion}

Field applications of insecticides to agricultural crops can lead to a decline of soil microbiota that can affect the diversity of the microbial community and disrupt ecosystem function that impacts upon plant growth, nutrient cycling, and mineralization of soil-amended crop residues. Microbes (bacteria and fungi) that adapt to the insecticide residues in arable soils will have the ability to degrade them, and ideally these are sought for studies on bioremediation of these xenobiotic compounds. Additionally, tropical insect pests such as Anticarsia gemmatalis, which feed-off and damage the foliage of soybean plants, harbor microbiota that too may serve as a source of microbes to metabolize insecticides, esp., when soybean crops have been sprayed with insecticides.

\section{Assessment of fungal growth on the commercial insecticides: Actara ${ }^{\circledR}$ and Belt ${ }^{\circledR}$}

Insecticide residues usually appear within the top $15-\mathrm{cm}$ soil layer, the region with greatest microbial activity providing a platform for their interaction with insecticide residues, and the soil dynamics will impact on this.

A total of 133 fungi were isolated from the soil, where soybeans had been cultivated, and where the commercial insecticides: PlatinumNeo® (thiamethoxam) and Prêmio ${ }^{\circledR}$ (chlorantraniliprole) had been applied over a period of several years. Chlorantraniliprole belongs to the ryanoid class of alkaloid ryanodines that also includes flubendiamide. Fungi labeled as JUSOLCL were isolated from soils where Prêmio® had been applied to soybean crops, while JUSOLTH-labeled fungi were collected from soil where PlatinumNeo® was applied. Fungi labeled SOL were taken from insecticide-free soil (see Fig. 2) and Tables 2 and 3 for the coded fungal isolates).

Of the fungal isolates collected from the soils, 10 fungi demonstrated rapid growth on PDA medium and were selected for study on the growth inhibition tests using the commercial insecticides Actara ${ }^{\circledR}$ and Belt $\circledast$. In addition, the endophytic fungus $B$. rhodina MAMB-05 (an ascomycete isolated from a canker on the trunk of an eucalyptus tree; Barbosa et al. 1996), and 2 entomopathogenic fungi (JUANT001 and JUANT070) isolated from larvae of the tropical insect, Anticarsia gemmatalis, that infests soybean crops, were also included in the growth inhibition tests. Figure 2 shows the 13 fungi chosen for the growth inhibition assessments.

\section{Physiochemical properties of soils where insecticides were applied}

Fungi isolated from the distroferric red latosol soils of the Londrina region contaminated with insecticides over a period of several years survived the application of these pesticides, and furthermore, were capable of high growth capacity when cultivated in the lab on nutrient (PDA) medium. Such observations indicated that this community of fungal species in the field possessed the potential of degrading insecticides and find applications in bioremediation.

Data on the physicochemical parameters of the distroferric red latosol soils from the farm sectors where insecticides were applied were representative of soils sampled on 29 May 2014 are shown in Table 1. The soils showed different proportions of clay, silt, and sand. The highest content was clay, which is characteristic of distroferric red latosol soils, while the proportion of silt and sand was considerably lower. The soils for the three farm sectors were slightly acidic with $\mathrm{pH}$ ranging from 5.0 to 5.5. The applications of insecticide did not vary the soil $\mathrm{pH}$. The mineral contents (measured in elemental form by atomic absorption spectroscopy) showed minor differences between the sectors applied with insecticide compared with its absence. In soil where Prêmio ${ }^{\circledR}$ was applied, lower values for the various elements were found compared with the soil where no insecticide had been applied, or the sector applied with PlatinumNeo®. The variations were not considerably different. The highest amount was for carbon, which probably reflects plant residues in the soils and their colonization with microbial biomass, followed next by phosphorus. The amounts of calcium varied between the soils, while $\mathrm{K}$ and $\mathrm{Mg}$ contents were fairly low. No aluminum was present in any of the soils sampled from the different farm sectors. The chemical composition, with the exception of soil $\mathrm{pH}$ and $\mathrm{Al}$, was distinctly different to the dystrophic red latosol soil in which soybean crops were grown in a different region in Brazil (Zuffo et al. 2015).

The soil ecosystem is a complex matrix inhabited by a biodiverse community that includes bacteria and fungi among others. The importance of the physicochemical properties and texture of soils where pesticides have been applied influences the microbial community and diversity in the soil, facilitating them to survive and metabolize the pesticides (Jacobsen and Hjelmsø 2014). Additionally, the dissipation and persistence of pesticides (e.g., flubendiamide) in field soils depended upon the soil properties - moisture and organic matter (Das and Mukherjee 2012). 


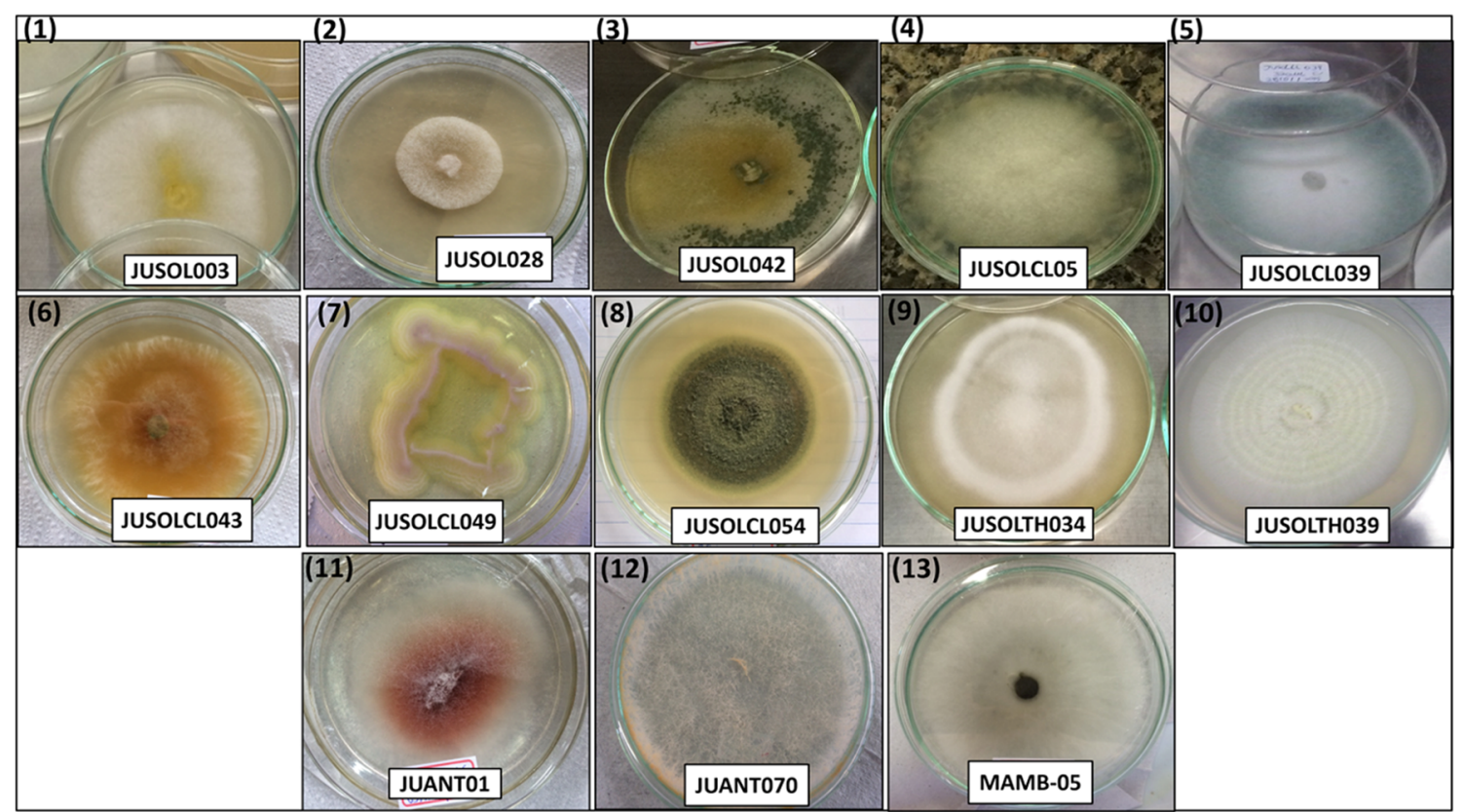

Fig. 2 Selected soil and insect fungal isolates grown on potato-dextroseagar medium. JUSOL003 (1); JUSOL028 (2); JUSOLCL039 (3); JUSOLCL05 (4); JUSOLTH034 (5); JUSOLTH039 (6); JUSOLCL043 (7); JUSOLCL049 (8); JUSOLCL054 (9); JUSOL042 (10); JUANT001

\section{Growth inhibition tests}

In developing the growth inhibition tests, $B$. rhodina MAMB05 was selected as the reference fungus, as it was known to degrade the herbicide Imazaquin (Rezende et al. 2005), and could therefore have the capacity to degrade the commercial insecticides Actara ${ }^{\circledR}$ and Belt $\AA$, whose active principles are thiamethoxam and flubendiamide, respectively. Four concentrations of each of the insecticides (Actara ${ }^{\circledR}-3,7,21$, and $35 \mathrm{~g} / \mathrm{L}$; and Belt ${ }^{\circledR}-1.22,4.88,19.52$, and $\left.39.04 \mathrm{~g} / \mathrm{L}\right)$ containing thiamethoxam (25\%) and flubendiamide (48\%),
(11); JUANT070 (12); and Botryosphaeria rhodina MAMB-05 (13). Numbers 1-10 represent soil fungal isolates; 11 and 12, fungal isolates from the tropical insect larva (Anticarsia gemmatalis); and 13, an endophytic ascomycete

respectively, incorporated in solid (PDA) media were chosen to screen 10 soil fungal isolates, 2 fungal isolates from insect larva, and B. rhodina MAMB-05, in the evaluation of growth inhibition under low, intermediate, and high concentrations of the insecticides (see Supplementary Material Figures 4 and 5). These concentration ranges were assessed to determine the concentrations at which fungal growth was inhibited at $50 \%$ relative to the control, which were interpreted as being toxic to the fungi. The mathematical Knott-Scott test was used to statistically evaluate the toxicity significance among the 13 fungi studied. Growth inhibition was evaluated relative to the same
Table 1 Physical and chemical properties of the distroferric red latosol soils taken from three different sectors on a farm in the Londrina region that had been were treated with different pesticides

\begin{tabular}{llll}
\hline Physicochemical parameters* & \multicolumn{2}{l}{ Farm sectors where insecticides were applied } \\
\cline { 2 - 4 } & PlatinumNeo® & Prêmio® & No. of insecticides \\
\hline Clay $(\mathrm{g} / \mathrm{kg})$ & 68.00 & 67.00 & 69.00 \\
Silt $(\mathrm{g} / \mathrm{kg})$ & 15.00 & 18.00 & 15.00 \\
Sand $(\mathrm{g} / \mathrm{kg})$ & 17.00 & 15.00 & 17.00 \\
$\mathrm{pH}$ & 5.50 & 5.00 & 5.40 \\
$\mathrm{P}\left(\mathrm{mg} / \mathrm{dm}^{3}\right)$ & 16.90 & 14.60 & 18.50 \\
$\mathrm{C}\left(\mathrm{g} / \mathrm{dm}^{3}\right)$ & 18.07 & 17.64 & 20.18 \\
$\mathrm{Al}\left(\mathrm{cmol} / \mathrm{dm}^{3}\right.$ soil $)$ & 0 & 0 & 0 \\
$\mathrm{Ca}\left(\mathrm{cmol} / \mathrm{dm}^{3}\right.$ soil $)$ & 7.10 & 5.62 & 6.02 \\
$\mathrm{Mg}\left(\mathrm{cmol} / \mathrm{dm}^{3}\right.$ soil $)$ & 1.89 & 1.23 & 1.64 \\
$\mathrm{~K}\left(\mathrm{cmol} / \mathrm{dm}^{3}\right.$ soil $)$ & 1.12 & 0.81 & 1.35 \\
\hline
\end{tabular}

*Evaluated on 05/29/2014; cmol, centimoles 
fungal isolates grown on media in the absence of both insecticides. The results of the inhibition of growth by the fungi on the insecticides Actara ${ }^{\circledR}$ and Belt ${ }^{\circledR}$ are shown in Tables 2 and 3.

The presence of the insecticide Actara ${ }^{\circledR}$ statistically influenced the growth of all of the evaluated fungi at all of the concentrations examined, with the exception of isolate JUANT070, which was not inhibited at $3 \mathrm{~g} / \mathrm{L}$. In summary, at the highest concentration of Actara ${ }^{\circledR}$ evaluated $(35 \mathrm{~g} / \mathrm{L})$, fungal isolates exhibiting the lowest degree of inhibition of growth were as follows: JUANT070 (48.41\%), JUSOLCL039 (75.97\%), and B. rhodina MAMB-05 (79.23\%). A similar examination with Belt $\AA$ demonstrated that at low concentrations (1.22 and $4.88 \mathrm{~g} / \mathrm{L})$, several isolates including JUANT070 and JUSOLCL039 were not inhibited. By comparison, B. rhodina MAMB-05 was inhibited to the extent of 1.72 and $8.07 \%$, respectively. At the highest concentration of Belt ${ }^{\circ}$ examined (39.04 g/L), JUANT070 was not inhibited, while JUSOLCL039 and B. rhodina MAMB-05 were inhibited to the extent of 5.42 and $43.39 \%$, resp. Because fungal isolates JUANT070 and MAMB-05 tolerated high concentrations of the insecticides, they were selected for further studies on the biodegradation of flubendiamide.

In tests with fungi at the laboratory-scale level, it is essential to obtain rates of growth above which can be expected from fungi growing in the environment (field) where pesticides have been applied. Thus, the concentrations of insecticides tested in the laboratory corresponded to values much higher than the doses actually applied to agricultural crops such as soybeans in the field, which are exceptionally low; Actara ${ }^{\circledR}: 0.12-0.20 \mathrm{~g} / \mathrm{L}$ (https://www.syngenta.com.br/ product/crop-protection/inseticida/actara-250-wg), and Belt $®$ : $0.05-0.25 \mathrm{~g} / \mathrm{L}$ ) (https://www.agro.bayer.com.br/ produtos/belt). Preliminarily tests on the 13 fungal isolates at these field concentrations of insecticides showed no inhibition by the fungal isolates examined.

The evaluation of the growth inhibition tests using Actara ${ }^{\circledR}$ and Belt $\AA$ allowed the selection of fungi with potential to biologically degrade insecticides with greater capacity. The results of the evaluations of growth on the two insecticides demonstrated that isolates JUANT070 and JUSOLCL039 performed best in tolerating high concentrations of both insecticides (Tables 2 and 3). Next was B. rhodina MAMB-05, which also showed satisfactory growth, mainly with Actara ${ }^{\circledR}$, where few of the other fungi tested were able to grow. With the insecticide Belt ${ }^{\circ}$, its inhibition was also highlighted, as it did not exceed $50 \%$ at the highest concentration tested. Consequently, two fungal isolates, JUANT070 and MAMB-05, were selected for the biodegradation experiments in submerged liquid cultivation.

Fungi of the genera Trichoderma and Neurospora have presented a history of participation of the biodegradation of xenobiotic compounds, and in several cases produced the enzyme, laccase (Su et al. 2010). In addition, Birolli et al. (2015) evaluated the biodegradative potential of Trichoderma sp. in the presence of the organochloride insecticide, dieldrin. In
Table 2 Growth inhibition of selected fungi isolated from soil and insect larva that were cultivated on PDA medium containing different concentrations of the commercial insecticide Actara ${ }^{\circledR}$. Botryosphaeria rhodina MAMB05 was used as a reference

\begin{tabular}{|c|c|c|c|c|}
\hline \multicolumn{5}{|l|}{ Growth inhibition $(\%)^{*}$} \\
\hline \multirow[t]{2}{*}{ Fungal isolates } & \multicolumn{4}{|c|}{ Concentration of Actara ${ }^{\circledR}(\mathrm{g} / \mathrm{L})$} \\
\hline & 3 & 7 & 21 & 35 \\
\hline Neurospora sp. JUANT070 & $00.00 \pm 0.00^{\mathrm{cD}}$ & $04.10 \pm 1.03^{\mathrm{cF}}$ & $35.18 \pm 1.03^{\mathrm{bF}}$ & $48.41 \pm 0.61^{\mathrm{aE}}$ \\
\hline JUSOLTH039 & $01.34 \pm 0.28^{\mathrm{dD}}$ & $20.57 \pm 4.09^{\mathrm{cD}}$ & $61.70 \pm 2.68^{\mathrm{bD}}$ & $72.31 \pm 2.47^{\mathrm{aD}}$ \\
\hline JUSOLCL054 & $02.64 \pm 1.40^{\mathrm{dD}}$ & $42.33 \pm 0.53^{\mathrm{cC}}$ & $67.62 \pm 2.31^{\mathrm{bC}}$ & $75.55 \pm 2.47^{\mathrm{aD}}$ \\
\hline JUSOLCL043 & $02.91 \pm 0.35^{\mathrm{dD}}$ & $17.06 \pm 0.92^{\mathrm{cE}}$ & $61.24 \pm 2.68^{\mathrm{bD}}$ & $85.71 \pm 0.46^{\mathrm{aD}}$ \\
\hline $\begin{array}{l}\text { Trichoderma koningiopsis } \\
\text { JUSOLCL039 }\end{array}$ & $03.97 \pm 3.97^{\mathrm{dD}}$ & $21.69 \pm 1.40^{\mathrm{cD}}$ & $43.25 \pm 3.99^{\mathrm{bE}}$ & $75.97 \pm 3.37^{\mathrm{aD}}$ \\
\hline JUSOL003 & $03.57 \pm 1.82^{\mathrm{dD}}$ & $35.18 \pm 9.01^{\mathrm{cC}}$ & $80.42 \pm 3.45^{\mathrm{bB}}$ & $92.73 \pm 0.13^{\mathrm{aA}}$ \\
\hline JUSOL042 & $03.44 \pm 3.44^{\mathrm{cD}}$ & $59.92 \pm 0.83^{\mathrm{bB}}$ & $76.06 \pm 3.95^{\mathrm{aB}}$ & $81.35 \pm 1.05^{\mathrm{aC}}$ \\
\hline JUSOL028 & $07.54 \pm 0.61^{\mathrm{dC}}$ & $38.36 \pm 1.06^{\mathrm{cC}}$ & $69.58 \pm 0.74^{\mathrm{bC}}$ & $82.67 \pm 1.34^{\mathrm{aC}}$ \\
\hline JUANT001 & $09.13 \pm 3.08^{\mathrm{dC}}$ & $25.92 \pm 3.25^{\mathrm{cD}}$ & $67.32 \pm 3.51^{\mathrm{bC}}$ & $77.28 \pm 0.00^{\mathrm{aC}}$ \\
\hline JUSOLCL005 & $11.75 \pm 5.02^{\mathrm{cC}}$ & $68.91 \pm 1.72^{\mathrm{bA}}$ & $89.42 \pm 1.13^{\mathrm{aA}}$ & $96.56 \pm 0.58^{\mathrm{aA}}$ \\
\hline JUSOLTH034 & $18.94 \pm 2.21^{\mathrm{cB}}$ & $22.98 \pm 1.87^{\mathrm{cD}}$ & $80.64 \pm 1.41^{\mathrm{bB}}$ & $90.20 \pm 0.00^{\mathrm{aB}}$ \\
\hline JUSOLCL049 & $29.91 \pm 1.01^{\mathrm{cA}}$ & $33.56 \pm 3.33^{\mathrm{cC}}$ & $72.31 \pm 4.04^{\mathrm{bC}}$ & $90.10 \pm 1.36^{\mathrm{aB}}$ \\
\hline Botryosphaeria rhodina MAMB-05 & $05.42 \pm 1.72^{\mathrm{dD}}$ & $14.95 \pm 2.18^{\mathrm{cE}}$ & $70.50 \pm 1.84^{\mathrm{bC}}$ & $79.23 \pm 0.93^{\mathrm{aC}}$ \\
\hline
\end{tabular}

*Means \pm SEM followed by the same letter do not differ statistically from one another, lower case in the row and upper case in the column, according to the Scott-Knott test at $5 \%$ probability. Growth inhibition was estimated from measurements of the colony radii $(\mathrm{cm})$ of the growing fungal colonies on the agar plates compared with control cultures containing no insecticides 
Table 3 Growth inhibition of selected fungi isolated from soil and insect larva that were cultivated on PDA medium containing several concentrations of the commercial insecticide Belt®. Botryosphaeria rhodina MAMB-05 was used as a reference

\begin{tabular}{|c|c|c|c|c|}
\hline \multirow[t]{2}{*}{ Fungal isolates } & \multicolumn{4}{|c|}{ Concentration of Belt巴 $(\mathrm{g} / \mathrm{L})$} \\
\hline & 1.22 & 4.88 & 19.52 & 39.04 \\
\hline JUSOL042 & $00.00 \pm 0.00^{\mathrm{aC}}$ & $00.00 \pm 0.00^{\mathrm{aD}}$ & $04.43 \pm 1.16^{\mathrm{aD}}$ & $08.06 \pm 2.29^{\mathrm{aE}}$ \\
\hline JUSOL028 & $00.00 \pm 0.00^{\mathrm{bC}}$ & $13.26 \pm 3.48^{\mathrm{aC}}$ & $15.48 \pm 5.81^{\mathrm{aC}}$ & $17.07 \pm 1.73^{\mathrm{aD}}$ \\
\hline $\begin{array}{l}\text { Trichoderma koningiopsis } \\
\text { JUSOLCL039 }\end{array}$ & $00.00 \pm 0.00^{\mathrm{aC}}$ & $00.00 \pm 0.00^{\mathrm{aD}}$ & $01.85 \pm 0.13^{\mathrm{aD}}$ & $05.42 \pm 1.66^{\mathrm{aE}}$ \\
\hline JUSOLCL043 & $00.00 \pm 0.00^{\mathrm{aC}}$ & $01.19 \pm 1+19^{\mathrm{aD}}$ & $02.91 \pm 2.17^{\mathrm{aD}}$ & $06.22 \pm 0.80^{\mathrm{aE}}$ \\
\hline Neurospora sp. JUANT070 & $00.00 \pm 0.00^{\mathrm{aC}}$ & $00.00 \pm 0.00^{\mathrm{aD}}$ & $00.00 \pm 0.00^{\mathrm{aD}}$ & $00.00 \pm 0.00^{\mathrm{aE}}$ \\
\hline JUSOL003 & $00.00 \pm 0.00^{\mathrm{bC}}$ & $05.44 \pm 3.46^{\mathrm{bD}}$ & $14.28 \pm 1.21^{\mathrm{aC}}$ & $18.65 \pm 4.20^{\mathrm{aD}}$ \\
\hline JUSOLCL054 & $04.16 \pm 2.25^{\mathrm{bC}}$ & $08.50 \pm 0.66^{\mathrm{bC}}$ & $14.43 \pm 2.00^{\mathrm{aC}}$ & $15.78 \pm 1.42^{\mathrm{aD}}$ \\
\hline JUSOLCL005 & $07.32 \pm 2.44^{\mathrm{bC}}$ & $12.56 \pm 2.26^{\mathrm{bC}}$ & $33.47 \pm 7.70^{\mathrm{aB}}$ & $36.24 \pm 0.93^{\mathrm{aC}}$ \\
\hline JUANT001 & $14.11 \pm 1.47^{\mathrm{bB}}$ & $17.68 \pm 2.55^{\mathrm{bB}}$ & $29.04 \pm 3.18^{\mathrm{aB}}$ & $35.98 \pm 2.05^{\mathrm{aC}}$ \\
\hline JUSOLTH039 & $17.17 \pm 0.14^{\mathrm{cB}}$ & $23.27 \pm 1.41^{\mathrm{cB}}$ & $35.87 \pm 4.08^{\mathrm{bB}}$ & $50.83 \pm 2.88^{\mathrm{aB}}$ \\
\hline JUSOLTH034 & $18.94 \pm 2.21^{\mathrm{bB}}$ & $22.98 \pm 1.87^{\mathrm{bB}}$ & $27.99 \pm 4.92^{\mathrm{bB}}$ & $38.72 \pm 1.39^{\mathrm{aC}}$ \\
\hline JUSOLCL049 & $29.16 \pm 8.12^{\mathrm{dA}}$ & $46.89 \pm 6.39^{\mathrm{cA}}$ & $61.13 \pm 7.98^{\mathrm{bA}}$ & $75.20 \pm 5.42^{\mathrm{aA}}$ \\
\hline Botryosphaeria rhodina MAMB-05 & $01.72 \pm 0.93^{\mathrm{cC}}$ & $08.07 \pm 1.32^{\mathrm{cC}}$ & $31.22 \pm 3.77^{\mathrm{bB}}$ & $43.39 \pm 1.34^{\mathrm{aB}}$ \\
\hline
\end{tabular}

* Mean \pm SEM followed by the same letter do not differ statistically from one another, lower case in the row and upper case in the column, according to the Scott-Knott test at 5\% probability. Growth inhibition was estimated from measurements of the colony radii $(\mathrm{cm})$ of the growing fungal colonies on the agar plates compared with control cultures containing no insecticides their study, the authors highlighted that the growth of Trichoderma sp. was surpassed only by Penicillium miczynskii, another soil borne fungus.

The genus Neurospora has also been the target of biodegradation studies. According to de Jesus et al. (2010), the cultivation of this fungus in the presence of the commercial dye Erythrosine (an organoiodine compound containing 4 iodine groups used as a red food colorant) suggested the possibility of the enzymatic action of laccase in the biodegradation of this xenobiotic compound.

In conclusion, we believe that these fungi are promising candidates for use in bioremediation processes where environmental spills at high levels of these insecticides constitute pollutants that endanger the ecosystem and can impact on public health and safety.

\section{Molecular phylogenetic analyses and identification of the fungal isolates}

As isolates JUANT070 and JUSOLCL039 performed best in tolerating high concentrations of both insecticides, they were selected for further study, and were consequently chosen for molecular identification. Isolate JUANT070 formed an independent lineage inside a well-supported clade containing reference strains of Neurospora crassa, $N$. hispaniola, and $N$. tetrasperma, but could not be assigned to any of those species, and was named Neurospora sp. (Fig. 3a). Two closely related species also belong to this clade, viz., $N$. sitophila and
N. perkinsii (Villalta et al. 2009), but no RPB2 sequence from reference strains of these species was available to us for comparative purposes. The Trichoderma isolate JUSOLCL039 clustered with reference strains of Trichoderma koningiopsis in a well-supported clade in the Maximum Parsimony phylogenetic tree, and was named accordingly (Fig. 3b).

\section{Potential of flubendiamide and thiamethoxam inducing laccase formation by fungal isolates JUANT070, JUSOLCL039, and Botryosphaeria rhodina MAMB-05}

As laccases are known to attack a broad spectrum of chemical structures, viz., aromatic and phenolic compounds (Cannatelli and Ragauskas 2017; Agrawal et al. 2018), it was of interest to determine if these enzymes could also act on the insecticides flubendiamide and thiamethoxam causing their degradation, and this would shed information on biotransformation reactions.

Actara ${ }^{\circledR}$ and Belt ${ }^{\circledR}$ did not interfere with the assay of laccase activity, as no oxidation of ABTS was observed. Each of the evaluated fungi was found to produce laccase, but at low levels of activity $(0.01$ and $0.12 \mathrm{U} / \mathrm{mL})$ compared with the activities in the absence of the respective insecticides (between 0.01 and $0.16 \mathrm{U} / \mathrm{mL}$ ). This fact may be related to the vehicle in the preparations of these commercial insecticides, which make up the greater proportion of their composition, and which are present to confer inertness, solubility, and 

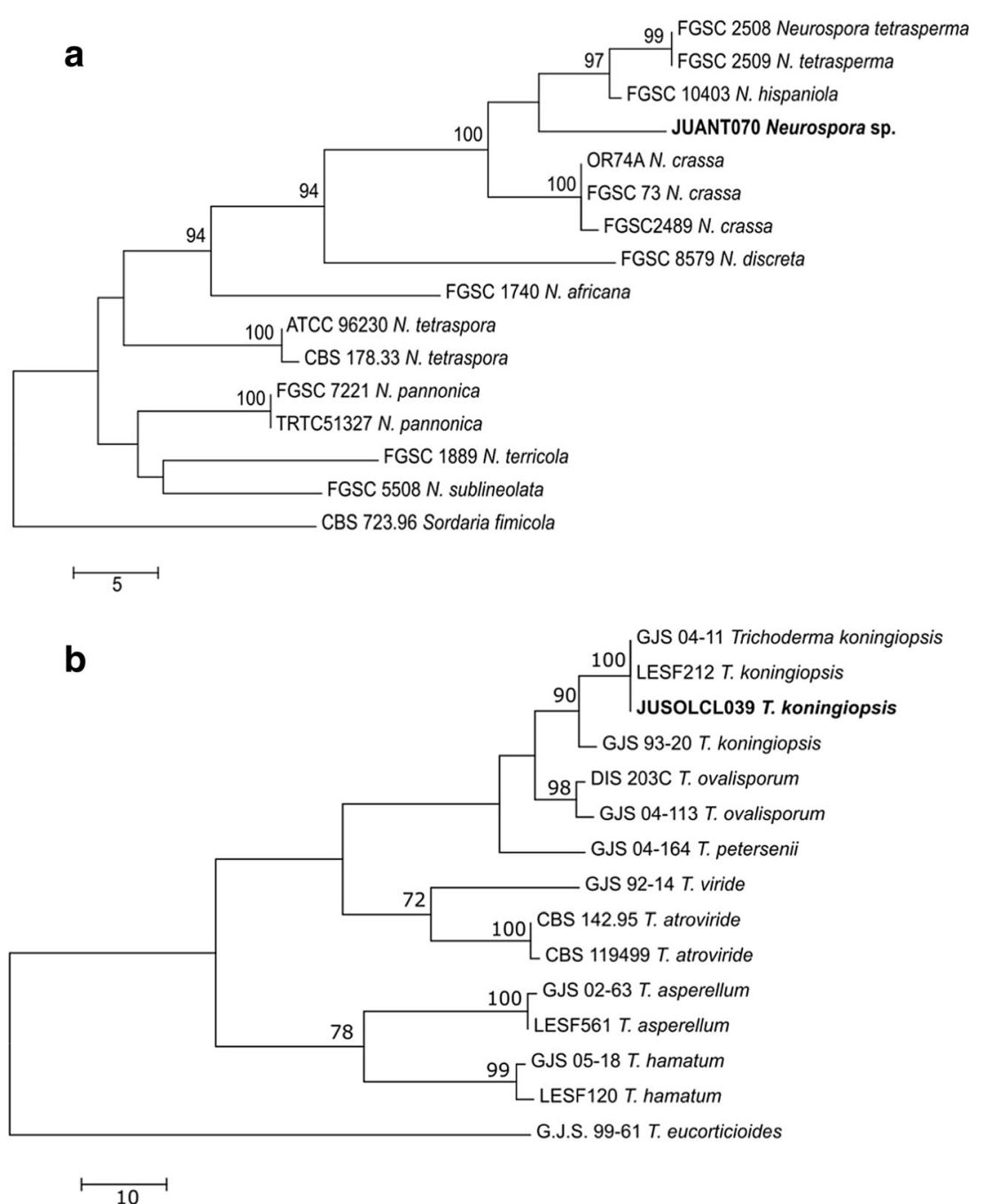

Fig. 3 Identification of strains JUANT070 and JUSOLCL039 using molecular phylogenetic analyses of partial DNA sequences of the RPB2 gene. a Maximum parsimony (MP) phylogenetic tree of Neurospora spp.; the tree was rooted with Sordaria fimicola CBS 723.96. b MP tree of Trichoderma spp. from the sub-genus Trichoderma; the tree was rooted with T. eucorticioides G.J.S 99-61. Bootstrap values equal or higher than $70 \%$ trees are shown by the nodes. (collection codes: CBS: CBS-KNAW,

stability to the insecticide active principle. The inert compounds that make up the commercial insecticides could possibly have interfered in the laccase production by the selected fungi. Enzymes such as laccase are susceptible to inactivation by salts and other chemicals that may be present in the commercial insecticide preparations. The commercial herbicide Scepter ${ }^{\circledR}$, whose active principle is imazaquin, by contrast, supported growth of $B$. rhodina MAMB- 05 when incorporated into nutrient media at concentrations of up to $25 \%$ producing high levels of laccase activity, which was involved in the biodegradation of this xenobiotic compound (Rezende et al. 2005).

The influence of pure flubendiamide (analytical standard) on inducing laccase activity (assayed against ABTS
Fungal Biodiversity Centre culture collection, Utrecht, The Netherlands; DIS: CABI-Bioscience cultures and G.J.S.: personal collection of Gary J. Samuels, both held at the Systematic Mycology and Microbiology Laboratory (USDA-ARS-SMML); FGSC: Fungal Genetics Stock Center, Department of Plant Pathology, Kansas State University, Manhattan, KS USA; LESF, Laboratory of Ecology and Fungal Systematics, Universidade Estadual Paulista-UNESP, Rio Claro, Brazil)

as substrate) was evaluated in the growing fungal cultures at a concentration of $0.1 \mathrm{mg} / \mathrm{mL}$, and laccase activity at 10 days was compared with the absence of the insecticide. The laccase titers produced by isolate JUSOLCL039 in the presence of flubendiamide was $1.39 \pm 0.16 \mathrm{U} / \mathrm{mL}$, and in its absence a slightly higher activity resulted $(1.59 \pm 0.02 \mathrm{U} / \mathrm{mL})$. Under these conditions, flubendiamide is not considered to induce laccase activity by this fungus. Furthermore, the "control" results showed that the insecticide did not influence the oxidation of the substrate (ABTS). We conclude that isolate JUSOLCL039, molecularly identified as Trichoderma koningiopsis, is a constitutive, albeit low level producer of laccase, and the presence of the insecticide in the 
culture medium did not increase enzyme production above constitutive levels.

The quantification of laccase activity by isolate JUANT070 (Neurospora sp.) resulted in enzyme titers of $2.31 \pm 0.15 \mathrm{U} /$ $\mathrm{mL}$ in the presence of flubendiamide, and in its absence, similar levels of laccase (constitutive) were produced (2.27 \pm $0.29 \mathrm{U} / \mathrm{mL}$ ). The slight difference between the laccase activities obtained again demonstrated that flubendiamide did not influence induction of laccase.

B. rhodina MAMB-05 grown in the presence and absence of flubendiamide, by contrast, presented laccase activities considerably higher than the enzyme titers produced by the other fungal isolates examined. The addition of flubendiamide to the nutrient medium resulted in a laccase titer of $7.08 \pm$ $1.45 \mathrm{U} / \mathrm{mL}$, while in its absence, laccase activity was slightly lower $(6.67 \pm 1.01 \mathrm{U} / \mathrm{mL})$. The experiment was not conducted under optimized conditions, e.g., by the response surface method (RSM), which would result in higher enzyme titers (Vasconcelos et al. 2000). In addition, the results presented in the control revealed that there was no interference of flubendiamide in the oxidation of the substrate. $B$. rhodina MAMB-05 is known as an active producer of laccases, whose titers that can be enhanced above constitutive levels through the influence of nutrients (Dekker et al. 2007), and by the inducer, veratryl alcohol (Vasconcelos et al. 2000). More definitive studies would be are required (e.g., optimization by RSM) to demonstrate if flubendiamide is able to induce laccase to higher activity levels. Flubendiamide at the concentration used $(0.1 \mathrm{mg} / \mathrm{mL})$ did not inhibit growth of the 3 fungal isolates tested.

The influence of pure thiamethoxam to induce laccase activity was assessed on B. rhodina MAMB-05 and JUANT070, which were found to produce laccase titres when they were grown on nutrient media, and which diminished over a 15-day period. Highest activity was observed at 5 days, and resulted in the respective laccase titres of $2.71 \pm 0.25$ and $10.16 \pm$ $1.85 \mathrm{U} / \mathrm{mL}$, whereas in the absence of the insecticide, enzyme titres were $2.97 \pm 0.29$ and $0.07 \pm 0.08 \mathrm{U} / \mathrm{mL}$, respectively. Fungal isolate MAMB-05, in this case, produced far lower laccase titers than when cultivated on media in the presence of flubendiamide, and thus laccase was not considered to be induced on thiamethoxam. The decrease in laccase activity with time in both cases indicates the instability of the enzyme. Isolate JUANT070, by contrast, produced high laccase titers when grown in the presence of thiamethoxam; $10.16 \pm 1.9 \mathrm{U} /$ $\mathrm{mL}$ in 5 days, and this too decreased with time $(1.98 \pm 0.3 \mathrm{U} /$ $\mathrm{mL}$ at 10 days). In the absence of the insecticide, extremely low levels of laccase were produced during the course of fermentation (respectively, 0.07 to $0.04 \mathrm{U} / \mathrm{mL}$ at 5 and 10 days). From this observation, we conclude that thiamethoxam definitely acted as an inducer of laccase activity. JUANT070 belongs to the genus Neurospora, which is a notable laccase producer (Froehner and Eriksson 1974).

\section{Biodegradation of flubendiamide in vivo by isolate JUANT070 and Botryosphaeria rhodina MAMB-05, and in vitro by a laccase preparation from Botryosphaeria rhodina MAMB-05}

In vivo biodegradation reactions were conducted on flubendiamide by growing isolates JUANT070 and B. rhodina MAMB-05 on liquid media containing the pure insecticide for 20 days, and in vitro using a crude laccase preparation from B. rhodina MAMB-05. In both sets of experiments, the fungal mycelium and cell-free fermentation broth, as well as the laccase reaction mixture, were extracted with ethyl acetate. The percentage value of flubendiamide degradation was calculated by HPLC analysis from the area under the flubendiamide peak (retention time: $14.013 \mathrm{~min}$ ) in a calibration curve, and compared the samples of the combined fungal mycelia and the cell-free fermentation broth extracts, the extracts from laccase treatment, and control samples (flubendiamide without fungus).

Fungal isolate JUANT070 and B. rhodina MAMB-05 decreased the amount of flubendiamide by $27.4 \pm 5.9 \%$ and 9.5 $\pm 7.0 \%$, respectively, after a 20 -day cultivation period using an initial concentration of flubendiamide in the medium of $0.1 \mathrm{mg} / \mathrm{mL}$. The results demonstrated the potential of Neurospora sp. JUANT070 in the biodegradation of flubendiamide, which may be improved following statistical design experiments (e.g., RSM) to optimize conditions. The fungus Neurospora intermedia DP8-1, also an ascomycete, was reported as capable of degrading up to $99 \%$ of the herbicide, Diuron ${ }^{\circledR}$, within 3 days under the optimal degradation conditions (Wang et al. 2017).

The $B$. rhodina MAMB-05 laccase-catalyzed in vitro biodegradation of flubendiamide conducted at $\mathrm{pH} 6.5$ and $28^{\circ} \mathrm{C}$ for $24 \mathrm{~h}$ resulted in the removal of the insecticide by $20.2 \pm$ $6.6 \%$. The aforementioned studies indicated that laccase played an important role on the removal of flubendiamide by the two fungal isolates examined in this work. Other studies have revealed that laccase was involved in biotransformation reactions of iodination of phenolic compounds (Ihssen et al. 2014), and in the oxidative dehalogenation of a halogenated pesticide (Torres-Duarte et al. 2009).

Studies on the biodegradation of flubendiamide involving the soil bacterium, Chryseobacterium indologenes SSJ1, showed that $89.06 \%$ of the insecticide was removed within 5 days of treatment (Jadhav and David 2016). In another study, isolated soil bacteria molecularly identified as Micrococcus sp., Corynebacterium sp., and Pseudoxanthomonas sp., were claimed to be capable of degrading flubendiamide (Hegde et al. 2017).

To the authors knowledge there are no literature reports on the bioremediation of flubendiamide in submerged culture by fungi, nor of laccases degrading this particular insecticide. The work presented here, therefore, is the first report of its kind on the biodegradation of flubendiamide by filamentous fungi. 


\section{Conclusion}

Two fungal isolates selected on the basis of the results from growth inhibition tests on the insecticides Belt $\AA$ and Actara ${ }^{\circledR}$ were identified as Neurospora sp. (JUANT070) and Trichoderma koningiopsis (JUSOLCL039). These fungal isolates, as well as $B$. rhodina MAMB-05, and a crude laccase preparation from $B$. rhodina MAMB-05 were used in the biodegradation studies. Isolate JUANT070, produced high laccase titers when grown on thiamethoxam. B. rhodina MAMB-05 grown on flubendiamide presented laccase activities considerably higher than the laccase titers produced by JUANT070 and JUSOLCL039. Isolates JUANT070 and MAMB-05 treated with flubendiamide over a 20-day cultivation period decreased the amount of flubendiamide by $27.4 \%$ and $9.5 \%$ respectively., while a crude laccase preparation from B. rhodina MAMB-05 degraded flubendiamide in vitro by $20.2 \%$ over a 24 -h period. The results obtained indicate that Neurospora sp. (JUANT070) and B. rhodina MAMB-05 have potential for use in the bioremediation of environmental pollutants such as insecticides. This is the first study to report on the biodegradation of flubendiamide by filamentous fungi.

Funding information This work was supported by the International Foundation of Science, Sweden (grant 2014/F/4898-2) in partnership with Diretoria de Pesquisa e Pós-Graduação of Universidade Tecnológica Federal do Paraná, Londrina Câmpus, Brazil. Scholarships were provided by CNPq-Brazil (G.M. Yada Jr.) and Fundação AraucáriaBrazil (I.C. Araujo).

\section{Compliance with ethical standards}

Conflict of interest The authors declare that they have no conflict of interest.

Statement on the welfare of animals/statement of human rights This article does not contain any studies with human participants or animals performed by any of the authors.

Informed consent Informed consent was obtained from all individual participants included in the study.

Open Access This article is distributed under the terms of the Creative Commons Attribution 4.0 International License (http:// creativecommons.org/licenses/by/4.0/), which permits unrestricted use, distribution, and reproduction in any medium, provided you give appropriate credit to the original author(s) and the source, provide a link to the Creative Commons license, and indicate if changes were made.

\section{References}

Agrawal K, Chaturvedi V, Verma P (2018) Fungal laccase discovered but yet undiscovered. Bioresour Bioprocess 5(4):1-12

Alves SB (1998) Controle microbiano de insetos. FEALQ, Piracicaba
Barbosa AM, Dekker RFH, Hardy GES (1996) Veratryl alcohol as an inducer of laccase by an ascomycete, Botryosphaeria sp., when screened on the polymeric dye Poly R-478. Lett Appl Microbiol 23:93-96

Battu RS, Singh B, Kooner R, Singh B (2008) Simple and efficient method for the estimation of residues of flubendiamide and its metabolite desiodo flubendiamide. J Agric Food Chem 56:2299-2302

Birolli WG, Yamamoto KY, de Oliveira JR, Nitschke M, Seleghim MHR, Porto ALM (2015) Biotransformation of dieldrin by the marine fungus Penicillium miczynskii CBMAI 930. Biocatal Agric Biotechnol 4:39-43

Caldas S, Arias J, Rombaldi C, Mello L, Cerqueira M, Martins A, Primel $\mathrm{E}$ (2018) Occurrence of pesticides and ppcps in surface and drinking water in southern Brazil: data on 4-year monitoring. J Braz Chem Soc 30:71-80

Cannatelli MD, Ragauskas AJ (2017) Two decades of laccases: advancing sustainability in the chemical industry. Chem Rec 17:122-140

Chaverri P, Branco-Rocha F, Jaklitsch W, Gazis R, Degenkolb T, Samuels GJ (2015) Systematics of the Trichoderma harzianum species complex and the re-identification of commercial biocontrol strains. Mycologia 107:558-590

Colla LM, Primaz AL, de Lima M, Bertolin TE, Costa JAV (2008) Isolation and screening of fungi to bioremediation from triazine herbicide contaminated soil. Ciênc Agrotec 32:809-813

Das SK, Mukherjee I (2012) Effect of moisture and organic manure on persistence of flubendiamide in soil. Bull Environ Contam Toxicol $88: 515-520$

Das SK, Mukherjee I, Roy A (2017) Flubendiamide as new generation insecticide in plant toxicology: a policy paper. Adv Clin Toxicol 2: 10

de Jesus GJ, Corso CR, Campos A, Franchetti SMM (2010) Biodegradation of erythrosin B dye by paramorphic Neurospora crassa 74A. Braz Arch Biol Technol 53:473-480

Dekker RFH, Barbosa AM (2001) The effects of aeration and veratryl alcohol on the production of two laccases by the ascomycete Botryosphaeria sp. Enzym Microb Technol 28:81-88

Dekker RFH, Barbosa AM, Sargent K (2002) The effect of lignin-related compounds on the growth and production of laccases by the ascomycete, Botryosphaeria sp. Enzym Microb Technol 30:374-380

Dekker RFH, Barbosa AM, Giese EC, Godoy SDS, Covizzi LG (2007) Influence of nutrients on enhancing laccase production by Botryosphaeria rhodina MAMB-05. Int Microbiol 10:177-185

Domsch, K.H., Gams, W., Anderson, T.H. (2007) Compendium of soil fungi, 2nd Edn., Taxonomically revised by W. Gams. Eching: IHWVerlag, 2007. $672 \mathrm{pp}$.

Froehner SC, Eriksson KE (1974) Purification and properties of Neurospora crassa laccase. J Bacteriol 120:458-465

Grigoriev IV, Nikitin R, Haridas S, Kuo A, Ohm R, Otillar R, Riley R, Salamov A, Zhao X, Korzeniewski F, Smirnova T, Nordberg H, Dubchak I, Shabalov I (2014) MycoCosm portal: gearing up for 1000 fungal genomes. Nucleic Acids Res 42(D1):D699-D704

Hegde DR, Manoharan T, Sridar R (2017) Identification and characterization of soil bacterial isolates and their role in the degradation of flubendiamide insecticide in the artificial medium. J Entomol Zool Stud 5:1383-1387

Ihssen J, Schubert M, Thöny-Meyer L, Richter M (2014) Laccase catalyzed synthesis of iodinated phenolic compounds with antifungal activity. PLoS One 9:e89924

Jacobsen CS, Hjelmsø MH (2014) Agricultural soils, pesticides and microbial diversity. Curr Opin Biotechnol 27:15-20

Jadhav SS, David M (2016) Biodegradation of flubendiamide by a newly isolated Chryseobacterium sp. strain SSJ1. 3 Biotech 6:31

Lemos RC, Santos RD (1984) Manual de Descrição e Coleta de Solo no Campo, 2nd edn, Editora: Sociedade Brasileira de Ciência do Solo, Campinas-SP, Brazil, 48pp 
Liu YJ, Whelen S, Hall BD (1999) Phylogenetic relationships among ascomycetes: evidence from an RNA polymerse II subunit. Mol Biol Evol 16:1799-1808

Masaki T, Yasokawa N, Tohnishi M, Nishimatsu T, Tsubata K, Inoue K, Motoba K, Hirooka T (2006) Flubendiamide, a novel $\mathrm{Ca}^{2+}$ channel modulator, reveals evidence for functional cooperation between $\mathrm{Ca}^{2+}$ pumps and $\mathrm{Ca}^{2+}$ release. Mol Pharmacol 69:1733-1739

Montoya QV, Meirelles LA, Chaverri P, Rodrigues A (2016) Unraveling Trichoderma species in the attine ant environment: description of three new taxa. Antonie Van Leeuwenhoek 109:633-651

Rezende MI, Barbosa AM, Vasconcelos AFD, Haddad R, Dekker RFH (2005) Growth and production of laccases by the ligninolytic fungi, Pleurotus ostreatus and Botryosphaeria rhodina, cultured on basal medium containing the herbicide, Scepter® (Imazaquin). J Basic Microbiol 45:460-469

Rodrigues EG, Lírio VS, Lacaz, C. da S. (1992) Preservação de fungos e actinomicetos de interesse médico em água destilada. Rev Inst Med Trop Sao Paulo 34:159-165

Ruegger MJS, Tauk-Tornisielo SM (2004) Atividade da celulase de fungos isolados do solo da Estação Ecológica de Juréia-Itatins, São Paulo, Brazil. Braz J Bot 27:205-211

Su S, Zeng X, Bai L, Jiang X, Li L (2010) Bioaccumulation and biovolatilisation of pentavalent arsenic by Penicillin janthinellum, Fusarium oxysporum and Trichoderma asperellum under laboratory conditions. Curr Microbiol 61:261-266

Torres-Duarte C, Roman R, Tinoco R, Vazquez-Duhalt R (2009) Halogenated pesticide transformation by a laccase-mediator system. Chemosphere 77:687-692
United States of America, Environmental Protection Agency. Flubendiamide, 2008. https://www3.epa.gov/pesticides/chem search/reg_actions/registration/fs_PC-027602_01-Aug-08.pdf (Accessed 17 September 2019)

Vasconcelos AFD, Barbosa AM, Dekker RFH, Scarminio IS, Rezende MI (2000) Optimization of laccase production by Botryosphaeria $\mathrm{sp}$. in the presence of veratryl alcohol by the response-surface method. Process Biochem 35:1131-1138

Villalta CF, Jacobson DJ, Taylor JW (2009) Three new phylogenetic and biological Neurospora species: $N$. hispaniola, $N$. metzenbergii and N. perkinsii. Mycologia 101:777-789

Vogel HJ (1956) A Convenient Growth Medium for Neurospora crassa. Microbiol Genet Bull 13:42-43

Wang Y, Li H, Feng G, Du L, Zeng D (2017) Biodegradation of diuron by an endophytic fungus Neurospora intermedia DP8-1 isolated from sugarcane and its potential for remediating diuron-contaminated soils. PLoS One 12:e0182556

Zuffo AM, Zuffo JM Jr, de Faria Dias SG, Milanez de Rezende P, Bruzi AT, Zambiazzi EV, Soares IO (2015) Levels and phases of defoliation affect biomass production of pearl millet ADR 300. Afr J Agric Res 10:2784-2790

Publisher's note Springer Nature remains neutral with regard to jurisdictional claims in published maps and institutional affiliations. 